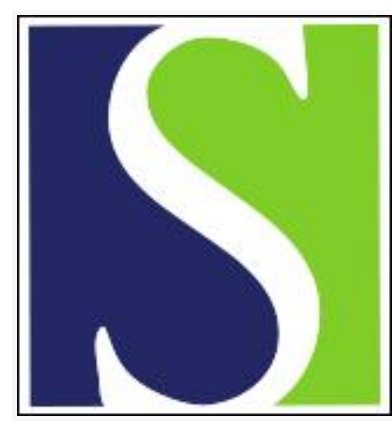

Scand J Work Environ Health 1998;24(2):85-97

https://doi.org/10.5271/sjweh.284

Issue date: Apr 1998

\title{
Health and productivity of older workers
}

by Robertson A, Tracy CS

The following article refers to this text: 2003;29(6):468-477

Key terms: older worker; review; work capacity; workforce aging

This article in PubMed: www.ncbi.nlm.nih.gov/pubmed/9630055

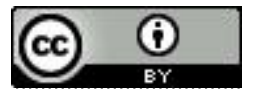




\title{
Health and productivity of older workers
}

\author{
by Ann Robertson, DrPH, ${ }^{1}$ C Shawn Tracy, $B S C^{2}$
}

\begin{abstract}
Robertson A, Tracy CS. Health and productivity of older workers. Scand J Work Environ Health 1998;24(2):5-97.
The purpose of this paper is to present a summary of a critical review of the literature on age, health, and work. The health of older workers is a concern to the extent that the productivity of older workers is considered to be a function of age-related health, the general conclusion being that age-related declines in health inevitably lead to decreased productivity. This paper investigates the implications of age-related physiological and psychological changes on the productivity of older workers, by focusing on a critical examination of the ways in which productivity has been conceptualized and operationalized. This paper concludes that the emerging concept of "work capacity" has the greatest potential for addressing the productivity issues of workforce aging. Implications for public and corporate policy and for further research are also examined.
\end{abstract}

Key terms older worker, review, work capacity, workforce aging.

\section{Introduction}

The very concept of "older worker" is relatively new to our contemporary cultural orientations. It is only in the last 15 to 20 years that the aging of the work force has become a policy priority, both in the public and corporate domains. This is a result of well-known and documented phenomena and forces that characterize the nature of Western industrialized society on the cusp of the 21 st century, such as a demographic shift towards an older population [sometimes referred to as the "squaring of the pyramid" (1)], the globalization of the economy, and the changing nature of work.

This paper presents a summary of a much longer review of the literature pertaining to age, health, and work (2), undertaken as part of a major research project on "Issues of an Aging Workforce" (IAW) funded by the federal government of Canada and conducted at the Institute for Human Development, Life Course and Aging, University of Toronto. ${ }^{3}$ While the number of publications on age and work is growing rapidly (3-6), the literature on age, health, and work is especially important to examine because many of the policies aimed at older workers are based on assumptions about the relationships among these 3 domains. Indeed, the literature reviewed reveals that the major issue in terms of the aging of the work force is a general concern that age-related declines in health inevitably lead to the decreased productivity of older workers (7-15).

\section{Attitudes towards older workers}

Peterson \& Coberly (16) highlight 5 important "myths" that are related, either directly or indirectly, to age-related changes among older workers (ie, declines) in health: (i) increased age results in generally poor health, loss of physical energy, and increased illness, leading to the assumption that older workers have a decreased capability to perform work tasks, a loss of stamina, and higher rates of absenteeism; (ii) increased age results in higher accident rates, more lost workdays, and increased insurance and medical costs, leading to the assumption that older workers are more expensive to a company, increase company risks, and are a danger to themselves and their co-workers; (iii) increased age results in lowered productivity because of slower actions, greater absence, and less commitment to the employer, leading to the assumption that older people cannot compete with younger workers; (iv) increased age results in a rigidity of behavior, an inability to learn new skills, and a rejection of innovative changes, leading to the assumption that older workers are not good candidates for retraining and challenging assignments that require learning new skills and work arrangements; and (v) increased age reduces the potential value of retraining,

1 Department of Public Health Sciences, University of Toronto, Toronto, Canada.

2 Institute for Human Development, Life Course and Aging, University of Toronto, Toronto, Canada.

3 IAW project working papers can be obtained from the Institute for Human Development, Life Course and Aging, 222 College Street, Suite 106, University of Toronto, Toronto, Ontario Canada M5T 3J1.

Reprint requests to: Dr Ann Robertson, Department of Public Health Sciences, McMurrich Building, University of Toronto, Toronto, Ontario Canada M5S 1A8. [e-mail: a.robertson@utoronto.ca] 
job development, and skill upgrading, leading to the assumption that older workers are not worth the investment of company resources (what has been called the "human capital argument").

According to one commentator (17), "the tragedy of ageist attitudes is that people tend to acquire them early in life but then reach the point where they are the targets of their own stereotypes" [p 42].

\section{Employment implications of attitudes towards older workers}

Data from the United States (18), the United Kingdom (14), and other industrialized countries $(19,20)$ indicate that the labor-force participation rates of older men, aged 55 to 64 years, have fallen dramatically in the post-World War II era, particularly since 1970. In Canada, unemployment data indicate that, while unemployment rates of older workers may be slightly lower than that of younger workers, the average duration of unemployment for Canadians aged 45 years and over is greater than it is for younger Canadians (21). Some researchers believe that official estimates of the unemployment rates of older people may hide the "emergence of [early] retirement as a disguised form of unemployment" [p 16] (21). Indeed, decreases in labor-force participation rates and increases in unemployment rates of older workers are explained in much of the literature in terms of the increase in the use of early retirement strategies aimed at older workers as a labor-market management strategy in times of decreased demand for labor $(14,21-23)$.

Research indicates that stereotypical attitudes are often reflected in the performance appraisals of older workers (24, 25 ), and data from the United States suggest that there is an age-related decline in earnings (26). Research in the United Kingdom indicates that, where older workers are being recruited into the labor force, it tends to be predominantly into part-time, low skill, low pay, low responsibility, and repetitive jobs (27). Lack of appropriate skills is often cited as being a major factor in discouraging the recruitment of older workers $(14,28)$. Some researchers have pointed out that, although discrimination against older workers operates across all socioeconomic groups, its greatest impact is on lower skilled groups (24).

\section{Scope of review}

While the longer review (2) from which this paper was adapted discusses conceptual issues related to "age" and "health" in detail, this paper focuses specifically on the literature related to the health and productivity of older workers. Much of the industrial and organizational psychology literature focuses on issues of productivity, and it is in this literature that we found considerable discussion of age-related changes in health. We also drew on the occupational health literature that concerned the adaptation of work tasks and the workplace to the worker.

Because of the vast amount of literature that pertains to issues of age, health, and work, many limitations were put on the scope of this review. In particular, while issues of gender, race or ethnicity, and class are clearly significant to the topic, the review did not address these issues directly.

\section{Health of older workers}

The study of aging and health requires attention to the biological, psychological, and social components, and the knowledge bases pertaining to each of these is growing rapidly in size, scope, and sophistication (29). Much of the literature on aging and health focuses primarily on health changes in people over 65 years of age and, therefore, was not especially useful for this review, which focuses on age-related health changes in the older worker population, people 40 to 65 years of age. ${ }^{4}$ For the purposes of this paper, the health of older workers is discussed in terms of the physiological and psychological changes associated with normal aging. ${ }^{5}$

\section{Physiological dimensions}

In this section, our discussion focuses on research on 3 major functions of the human body considered relevant to work, namely, sensory, motor, and cardiorespiratory function.

Sensory function. It is the changes in the auditory and visual senses that are of particular salience in a review of the effects of age on work (31). Although the changes are generally gradual and the impairments typically mild or moderate, and in spite of significant individual differences, the problem of hearing loss with age is unquestionably widespread (32). On account of well-documented age-related changes in auditory sensitivity $(30,33,35)$, older workers may well find themselves handicapped by their own work environments, which have been likely designed with younger workers in mind, as noted by Charness (36) and Charness $\& \operatorname{Bosman}(37-38)$.

Largely because of the high accessibility of the structures of the eye for scientific examination and study, the age-related changes that occur in the visual system are also well understood $(31,34,35)$. Changes in visual ability have implications for older workers, especially as work technology and organization continue to evolve (eg, the increased

4 The definition of "older worker" ranges from $>40$ years (30), based on the American Age Discrimination Act of 1986 , through $>45$ years $(11,15)$ to $>55$ years $(7)$.

5 This slant raises another whole domain of research, namely, the distinction between primary ("normal") and secondary ("pathological") aging. For a fuller discussion of issues related to this distinction, see the longer literature review (2) from which this paper was adapted. 
use of computers, the greater use of open workplace plans, etc). With age, both an increase in the size of visual detail and more intense lighting are often needed to work without difficulty, although excess light can result in glare and discomfort (36).

Motor function. Researchers have yet to determine the extent to which deterioration in motor function is due to aging per se or to other potential contributing causes, such as declining levels of physical activity and motivation, lowered societal expectations, and the occurrence of disease (39). While there are great individual differences in the nature, rate, and severity of age-related decline in human motor mechanisms (31), generally speaking, the effects of aging on motor performance tend to be both gradual and moderate. Although it remains unclear whether the intensity or duration of activity is more responsible for the decline in overall motor performance, it is known that the declines are greater for leisure activity than for on-the-job performance (40).

Declines in physical strength can largely be accounted for by the deterioration in muscle mass that occurs with aging (39). There is also an age-related decline in muscular endurance, albeit less than that for muscular strength. A probable reason for the lower age decline in activities involving endurance as opposed to strength is that compensatory strategies (such as the pacing of activity, for example) can be implemented that function to offset somewhat the effects of a loss of muscle tissue (40).

With respect to psychomotor behavior, the available evidence suggests lower degrees and rates of decline with age. In their recent review, Forteza \& Prieto (35) state that "the critical loss in these abilities is less pronounced ... and may be compensated by practice" [p 456]. Similarly, Stagner (33) notes that "in performing complex skilled jobs, it is possible that some perceptual skills (use of cues to align work properly, etc.) may compensate for any loss of motor coordination" [p 799]. Significant differences in reaction time also emerge with advancing age; the differences are small for simple tasks, but older workers react more and more slowly as complexity increases, especially when the stimuli are varied and appear at irregular intervals (41).

According to Welford (42), performance deficits with age will not appear until work demands exceed physical capacity. However, the greater heterogeneity of older age groups must be stressed again (39): "Evidence that interindividual variability in motor performance increases dramatically with increasing age is abundant. Therefore, descriptions of 'average' behavior for specific age groups grow less and less accurate for an individual's performance as the age of the group increases" [p 183].

Cardiorespiratory function. The combined functioning of the cardiovascular and respiratory systems - cardiorespiratory capacity - is an excellent index of overall physiological fitness, and therefore is the subject of much research. A recent report (15) from the World Health Organization (WHO) on aging and work outlines the substantial cardiovascular changes that occur with advancing age, including a decline in intrinsic myocardial contractile function, a $50 \%$ decline in ventricular filling between the ages of 20 and 80 years, and an increase in the time between aortic valve closure and mitral valve opening (ie, relaxation time) resulting in a decrease in maximum heart rate. The consequence of these age-related cardiovascular changes is a reduction in the maximal physical capacity of older workers; although cardiac output at rest tends not to change with age, declines in cardiac function in response to aerobic activity begin to appear by 40 years of age, but they do not normally pose problems with respect to work performance ( 43 as cited in 44 ).

The net result of the observed pattern of age-related decline in overall pulmonary function is a reduced capacity for extended periods of physical labor (15, 43 as cited in 44) and increased breathlessness with physical activity (45). While age-related alterations in the respiratory system may become problematic with the onset of respiratory disease, these changes do not normally pose a problem for older workers (43 as cited in 44). At the same time, it must be noted that the declines discussed in this section vary greatly with physical condition; therefore, older workers who strive to stay physically fit may be able to outperform more sedentary younger workers (39).

While it is clear from the literature that aging is accompanied by several physiological changes, it is also important to note the following (46): "Some processes appear to function adequately in older individuals under basal or resting conditions; the age-related deficit is brought out only when the system is stressed" [p 15 emphasis added].

\section{Psychological dimensions}

The following section reviews the current state of knowledge with respect to age-related declines in the psychological dimensions of health that have implications for work.

Cognitive competence. The concept of cognitive competence can be loosely defined (47) as "the degree of success in functioning within a specific environment" [p 318]. While considerable research has been and continues to be published on age and intellectual functioning, there has also been, as Schaie (48) points out, a recent turning away from simply studying the nature and extent of age differences and age changes in intelligence towards placing greater emphasis on individual patterns of change and on the identification of the factors that affect the rate of intellectual aging across the life course. The widely accepted myth of general intellectual deterioration with age is no longer sustainable. (For a detailed review of changes in intellectual abilities with age, see reference 49.) There is general agreement in the literature on several points. First, there is greater variability in the scores among people of a greater age; second, the decline on tests of mental speed is greater than on tests of mental power; 
and, third, there is a differentiation among abilities regarding the rate of deterioration $(48,50)$.

It appears that it is not until after the age of 70 that a marked decreased in performance is consistently observed, although age-related stability and even increases in intellectual or cognitive abilities have been reported up to the 7 th and 8th decade of life. Generally speaking, the cognitive losses that tend to be attributed to age occur largely among those who suffer cardiovascular illness or who endure impoverished sociocultural surroundings regardless of their age (35). Age-related changes in intellectual functioning are typically minimal for healthy workers who receive high levels of education and training and who are exposed to appropriate stimulation by their surroundings (35). There is also accumulating evidence that self-rated health status has a significant impact on cognitive performance (51-53).

Recent research indicates that the age-related decline in the information-processing capacity of older workers varies both by task complexity and by stress conditions (54). Older workers show the greatest decline in performance in complex tasks that require rapid decision making and that have to be carried out in noisy work environments (55).

Learning and memory. In contrast with earlier bleak evaluations of the capacity of older workers to learn $(56,57)$, there now exists a substantial amount of evidence documenting the continued learning capacity of older workers. Numerous studies have investigated age-related differences in the phases of acquisition, retention, and retrieval of information, and several recent reviews of this research focus particular attention on the implications for older workers $(15,35,58)$. For example, although older workers require more time and effort to encode information into the nervous system, once information has been encoded, future retrieval efforts are likely to be equally successful for older and younger workers $(15,35)$. It also appears that once older workers become relaxed and confident with their new environment they typically learn just as well - and just as rapidly — as younger workers (59).

Secondary or long-term memory has long been believed to be more susceptible to the effects of age than primary or short-term memory (60). Older adults may fail to retrieve specific information from long-term memory because it was never really learned in the first place (61), and, in any event, a decline in long-term memory may not be significant because older persons are usually able to adapt successfully to the change (15). Because older people perform less well in situations in which working memory (ie, a temporary storage mechanism) is heavily loaded (58), it may be that the older adult's difficulty lies primarily in the processing rather than storage aspects of memory. (See, for example, references 62 and 63.)

In terms of workplace training, Hultsch \& Dixon (64) note that "cognitive psychologists have increasingly begun to view [learning and memory] performance as a product of complex interactions among characteristics of both the task and the subjects performing it" [p 266]. Overall, later reviews $(35,61,65,66)$ reaffirm Birren's earlier conclusions that the changes in learning and memory typically experienced by older workers tend to be small, and they are likely more closely related to motivation level, attention, perception, health status, and the learning context itself than to some age-related incapacity to learn new skills (67). In general, current research indicates that the issue is no longer one of determining whether or not older workers can be trained, but rather one of isolating the best training approach(es), with a view to optimizing the training potential of older workers $(30,68,69)$.

Other psychological dimensions. It has been suggested in the literature that what may well be even more important to age-related work performance than the physiological and cognitive or perceptual factors already described are the general psychological changes that occur in a person over his or her life course. In a review of the effects of aging on employee productivity, Bourne (70) concludes that job satisfaction and work motivation - both contributors to higher productivity — are "probably most affected by psychological changes associated with the aging process" [p 44], specifically, adaptability or cognitive expertise (ie, the increased use of compensatory strategies), various personality factors (eg, locus of control), and identity and self-concept (ie, values, attitudes, and beliefs based on life experience and societal expectations).

Recent research into the relationships among age, health, and a sense of control demonstrates that interventions designed to increase the feelings of self-direction and the control of older persons (such as teaching them effective coping skills) result in improved cognitive problem-solving ability (71-73). In terms of the workplace, efforts to enhance the autonomy and decision latitude of older workers might well result in heightened levels of psychological well-being and performance.

In her study of adult identity, Whitbourne (74) demonstrates how changes in values, needs, and expectations at work appear to involve a continuous adjustment of personal interests and work environments. This line of research is suggestive of important interrelations among age, identity, and productivity - not to mention health. As Koyl (61) observes, "healthy older people may be very competent at handling stress as their experience in doing so is very broad" [p 54]. Similarly, work on "the hardy personality" suggests that the hardy worker might be expected to be more resistant to illness as a result of transforming workplace stress into challenge (75).

\section{Summary}

The foregoing review of the literature on the implications of age-related health changes for older workers reveals 2 major related issues that need to be examined further, namely, the 
significance of the adaptability and compensatory strategies of older workers and the determinants of the productivity of older workers.

In terms of the first issue, the role of experience in the relation of age to productivity has received increased attention of late $(76-78)$. A great benefit of years of on-the-job experience is increased job knowledge, variously referred to in the literature as professional mastery, expertise, adaptability, and the use of compensatory strategies. Studies have shown that jobs that are stimulating or that enhance skill development over time may positively affect productivity, while jobs that are simple or highly routine may over time produce workers who are unchallenged, bored, and eventually poor performers $(79,80)$.

While there is accumulating evidence that job experience is a better - that is, more valid and reliable - predictor of productivity than is chronological age (76-78), further scientific study is needed to determine whether observed agerelated differences in productivity can be reduced or eliminated with greater job experience (47).

\section{Productivity of older workers}

In this section, we discuss the third domain in the age, health, and work nexus, namely, productivity. We frame our discussion around 2 broad concepts of productivity that appear in the literature in relation to older workers: job performance and work capacity.

\section{Job performance and the older worker}

Job performance is the more conventional concept and historically is the most widely used measure of employee productivity, especially among employers and managers. With respect to older workers the belief persists that advancing age inevitably results in declining levels of on-the-job performance despite the absence of solid empirical support (81).

Researchers in the broad field of gerontology have, of late, devoted a great deal of attention to the issue of age and job performance. (See, for example, the narrative literature reviews of references 3,58 , and $82-85$; the meta-analyses of references 81 and 86 ; and a recent review article, reference 25 , that effectively combines both narrative and metaanalysis). This recent work notwithstanding, it is the 1983 exhaustive review of 28 empirical studies of the age-performance relationship by Doering et al (65) that is considered by many to be the definitive study of the aging employee. In these authors' view, the results are clearly mixed. In some cases, there is support for the commonly held belief that performance declines with age. Other studies provide evidence that the performance of older workers tends to be better in terms of accuracy and output consistency. Finally, a considerable number of studies shows a nonsignificant rela- tionship between age and level of performance. In a qualitative review of empirical investigations spanning 30 years of research, Rhodes (87) concludes that (i) when a person's unique abilities are matched to the organization's job requirements, good job performance results and (ii) when onthe-job experience is taken into account, performance tends to be the same across age groups.

Claiming that the qualitative approach used by Rhodes may result in "ambiguous or even erroneous interpretations" [p 33], Waldman \& Avolio (86) conducted a quantitative meta-analysis of 40 studies of age and job performance published between 1940 and 1983. Their findings indicate that chronological age accounts for only a small percentage of the variance in job performance; in fact, several of the specific results point to performance increments with advancing age. McEvoy \& Cascio (81) conducted a meta-analysis of 96 independent studies of aging and job performance, and their results indicate that "age and performance appear to be generally unrelated" [p 14]. Likewise, Sterns \& McDaniel (25) concluded more recently that "regardless of whether supervisory ratings or production criteria are used to define performance, the conclusion remains the same: the relationship between age and job performance is exceedingly weak" [p 31]. In any event, as Warr (84) argues, the "problem" of the older worker is a restricted one, and we should not expect to find decline in all aspects of job performance with advancing age since there are many general work activities in which age is a definite advantage or has negligible effects on performance.

Researchers specifically interested in age-related changes in job performance typically distinguish 2 dimensions, namely, work attitudes and work behavior. A brief summary of this research follows.

Work attitudes. The specific work attitudes addressed in this section include job satisfaction, work motivation, and organizational commitment. Detailed analyses of age and job satisfaction have tended to be few and far between over the years (87-91). Results of the studies published to date have tended to be mixed and generally inconclusive, despite 1 researcher's (87) assertion that "there is overwhelming evidence that overall job satisfaction is positively associated with age" [p 331].

Linked to job satisfaction is work motivation which, according to Doering et al (65), can be defined as "the degree to which the employee is motivated to perform well on the job because of some subjective rewards or feelings that he or she expects to receive as a result of performing well" [p 56]. This definition reflects the conceptual links between the work motivation literature and expectancy theory in the psychology literature. (See reference 70.) There is little research on the specific relation of age to motivation; in addition, the extent to which health status or health concerns may be implicated in the age-motivation relationship has yet to be explored. 
The concept of organizational commitment refers to the relative strength of a person's identification with and involvement in an organization (65). While the meta-analysis conducted by Mathieu \& Zajac (92) indicates a moderate positive correlation between age and organizational commitment, the general consensus in the literature remains that further research is warranted to clarify the nature of this relationship.

Work behavior. The accident, absenteeism, and turnover rates of older workers are among the most widely investigated aspects of the age-work relationship. Studies of age and workplace accidents suggest that the age-accident relationship is best characterized by 2 patterns of findings. First, the rate of workplace accident occurrence is negatively correlated with employee age - older workers are generally less likely to incur accidents than their younger counterparts (25, 93). Second, the severity of workplace accidents is positively correlated with employee age - workplace accidents involving older workers tend to result in more serious injuries (ie, permanent disability, dismemberment, or death) (94). The incidence of injury also varies by industry and occupation (95) and by level of on-the-job experience (96).

The literature is generally inconclusive as to the relationship between age and absenteeism $(97,98)$. It is often purported that, while older workers experience higher rates of unavoidable absence from work (as measured by absence duration), they have lower rates of avoidable absence (as measured by absence frequency) than do younger workers $(36,65,99)$. Based on her review of the available evidence, however, Rhodes (87) concluded that there is essentially no logical age-absence pattern for either avoidable or unavoidable absence from work.

In an early major review of employee turnover research, Porter \& Steers (100) stated that the "existing empirical evidence generally agrees that there is a strong negative relationship between increased age and turnover" [p 164]. As more recently noted by Sterns \& McDaniel (25), however, the current general consensus in the literature is clearly that age and employee turnover are inversely and only slightly related to one another $(58,65,87,101,102)$.

The relationship between health and employee turnover has been examined most specifically with respect to one kind of turnover, namely, exit from the labor force altogether (ie, retirement), especially regarding the influence of health on the timing of retirement $(103,104)$. According to McDonald $\&$ Wanner (105), the most enduring controversy in the retirement literature concerns whether health or financial status leads to early retirement - the so-called "health or wealth debate". For instance, some research indicates that health has a significant influence on the timing of retirement (106), especially early retirement (107). On the other hand, more recent data suggest that financial and economic factors have now surpassed health as the primary cause of early exit from the paid labor force $(108-111)$.

Conceptual limitations of job performance. As has been concluded elsewhere (112), the cumulative knowledge base on the effects of age-related changes in health on the productivity of older workers leaves much to be desired. For example, the enormous variability in performance among older workers has yet to be adequately captured by our current job performance measures. The International Labour Office (ILO) (10), in its recent World Labour Report, draws the conclusion that "the average difference in performance between age groups is typically significantly less than the variation within each age group. Older workers being a very heterogeneous group, differences in work performance should not a priori be attributed to age" [p 47, emphasis added]. Others note the need for further investigation into the heterogeneity within older age groups $(43,73)$.

Sterns \& Alexander (82, p 256) have identified 2 major conceptual limitations of job performance as an index of age-related productivity: (i) the failure to recognize that ageperformance relationships can differ substantially as a function of occupation or job requirements and (ii) the serious lack of reliable data sources, especially in view of the great problem of potential age bias in performance evaluation. Others have noted this need for better representative productivity data (113).

Another limitation of conventional methods of measuring employee productivity pertains to their failure to take into account the compensatory skills or strategies of older workers, referred to briefly earlier $(10,11,39)$. In summary, the ILO report (10) notes that "empirical research shows that because of their longer experience, older workers usually find ways to compensate for deficiencies and often still outperform younger workers" [ $p 47]$.

A final, and perhaps the most critical, limitation of conventional measures of the job performance of older workers concerns the extent to which it emphasizes functional capacity $(82,114)^{6}$ of the individual worker and ignores specific characteristics of the work itself - - work content, work environment, and work organization $(99,115)$. Rix (3) claims that "what appears to be an age-related performance decline may actually be the result of a mismatch between the job and the worker, which suggests that better matching of workers and jobs could result in a more productive work force" [p 68]. Alternatively, such declines in performance may be an indication that the workplace or the work itself, and not necessarily the worker, may be the problem. Current changes in the nature of work may also compound this issue (116). 


\section{Productive potential and the older worker in relation to the concept of work capacity}

We believe that the relationship between age-related changes in health and the productivity of older workers is more adequately captured in the concept of "work capacity". This emerging concept is the result of pioneering research being conducted in Scandinavia on the impact of work-related factors such as work content and organization (among other factors) on the productivity of older workers. Whereas the concept of job performance focuses exclusively on the attitudes and behaviors of individual older workers, the concept of work capacity requires that the productive potential of workers not be thought of only in terms of the capabilities of a person, but also in terms of the nature of the work itself, specifically work demands.

A recent report on work and aging (15) conceptualizes work capacity (also referred to as "work ability"7) as "a comprehensive term covering all the capacities necessary to perform a given type of work ... [and] therefore includes physical, mental, and social functional capacities" [p 3]. In this way the concept of work capacity goes far beyond the much narrower concept of functional capacity with its emphasis on individual worker characteristics, such as physical fitness, training, preexisting disease and disability, and the like.

Extensive research into developing a conceptual model of work capacity, which includes both individual worker characteristics and work and job characteristics, has been conducted in Europe, particularly in Finland (117-119) and The Netherlands $(120,121)$. For example, the Finnish Institute of Occupational Health has set its highest priority for the 1990s on "maintaining the work capacity" of the aging Finnish labor force, by focusing on 3 areas of investigation: the individual employee, the organization of the workplace, and the demands of the work itself (117).

Although various work-related variables, such as physical demands and environmental stressors, have long been implicated in the work-health relationship (122), age was unfortunately not often a consideration in this area of investigation; in fact, the majority of studies have used samples of young workers (probably for the sake of convenience). On the basis of a 4-year follow-up study of 6257 Finnish workers 45 to 58 years of age, covering the physical, mental, and mixed occupations, Ilmarinen and his associates (115) categorize work content, work environment, and work organization as the 3 main groups of risk factors for the older worker. Each of the 3 types of risks were found to predict accurately both the experienced decline in work capacity and the observed rate of retirement due to disability over the 4-year period of the study. Moreover, the results suggest that each of the factors in the 3 domains can singly increase the risk of a decline in work capacity and that the greater the number of factors to which an older worker is exposed the higher the overall risk of steep decline after 50 years of age.

The first of the 3 groups of risk factors that Ilmarinen (115) discusses is work content, or the actual set of tasks that together comprise any particular job. Earlier research has indicated that, since the physical ability required of work varies from occupation to occupation, the nature of the work itself (ie, the work content) is typically the most important determinant of the suitability of a worker for any given job (123). Work content factors have in common the presence of physical demands that are too high and, therefore, adversely affect the work capacity of workers. Several specific risks account for significant decreases in such capacity; they include static muscular work, use of muscular strength, lifting and carrying, sudden peak loads, repetitive movements, and simultaneously bent and twisted work postures. Job redesign efforts, directed toward lessening the load and harm potential, as described by Ilmarinen and his colleagues (115), can involve changing the content of a particular type of job (or more often of a single worker's job) by redistributing certain tasks, such as lifting and carrying, to other jobs in the organization (43). In addition, employers can selectively implement recent technological advances, such as automation, that have made possible the increased substitution of mechanical and electronic systems for physical exertion $(10,124)$.

The second group of work-related risk factors pertains to the nature of the work environment (115). The evidence demonstrates that a stressful and dangerous workplace significantly contributes to the deterioration of work capacity. Specific risk factors include dirty and wet workplaces, accident hazards, hot or cold workplaces, and changes in temperature during the workday $(10,15)$. Indeed, Jacobson's (125) earlier investigation of British factory employees' willingness to retire in relation to physical conditions of the job clearly demonstrates the need to consider the severity of demands placed on older workers by stress factors such as noise, dust, fumes, heat, and humidity. More recently, Mitchell et al (126) have presented data showing that, on the average, bluecollar workers retire earlier than do white-collar workers, with those employed in the service industry falling somewhere in between. In spite of these trends, however, much can be done in terms of workplace intervention to either prevent or reduce work limitations with a view to postponing retirement and extending worklife. One option is to make available to older workers advances that have been successful in optimizing the productive potential of handicapped employees, such as the specialized technical devices used to compensate for vision and hearing loss (124). There is also the alternative option of transferring older workers to lighter jobs where appropriate (10).

The organization of work is the third and final group of risk factors identified by Ilmarinen and his associates (115).

According to WHO (15), the term "work capacity" can be used synonymously with "work ability" when a specific class of work is being referred to. 
These factors, all highly typical of poorly organized work, include role conflicts, unsatisfactory supervision and planning of work, fear of failure and mistake, time pressure, lack of freedom of choice, lack of influence on own work, lack of professional development, and lack of acknowledgment and appreciation. Each of the items in this list, independent of the others, has been shown to contribute significantly to the deterioration of the work capacity of older workers (116). These findings would appear to corroborate the demandcontrol model of the psychosocial conditions of work developed by Karasek \& Theorell (127). If we combine the findings that situations of strain and increased risk of ill-health occur when demand exceeds control with our knowledge of age-related changes in health, the implications for the organization of work for an aging work force become increasingly clear $(65,128)$.

After examining these 3 domains of work-related risk factors, Ilmarinen and his associates (115) concluded that the additive effect of combining several different types of risks (eg, lifting plus heat plus time pressure) is a linear increase in the risk of decreased work capacity. While the overall pattern of workplace risk factors investigated did not vary significantly by gender, there were slight variations according to the health status of individual employees, and these slight variations may be associated with age. For example, the most harmful combination of risk factors for workers suffering from cardiovascular disease differs from that for those with either musculoskeletal disease or mental disorders (115). In an attempt to operationalize the concept of work capacity, researchers at the Finnish Institute for Occupational Health have developed a "work ability index" (115). This index represents a composite of standard measures of health status, such as the number of diagnosed diseases and the number of sick days within the past year, in combination with more subjective measures, such as estimations of present work ability in relation to physical and mental work demands (as a function of the nature of the work itself) and personal psychological resources.

We believe that the current and emerging work on conceptualizing and operationalizing the concept of work capacity represents the most innovative and promising line of research on the relationships among age, health, and the productivity of older workers. In order to integrate current and emerging thinking on the determinants of work capacity, efforts are being made to develop conceptual models of this construct $(117,119,121)$. In discussing a recent version of one such model, Ilmarinen (119) states that their "comprehensive model for promoting the work ability of aging workers . . is based on three groups of actions" [p 35], including actions in the work environment, including the organizational aspects of work, and improving the functional capacity of individual workers. In recognition of this interdependence between individual and structural factors in determining the work capacity of older workers, the ILO 1995 World Labour Report (10) concludes that "the degree to which working capacity meets work demands will affect productivity, and the difficulties that workers may encounter in meeting these demands may lead to stress and work-related diseases and disabilities" [p 46]. Therefore, as Ilmarinen and his associates recommend (117), "support for the older worker should always be combined with efforts in the workplace to adapt physical working conditions to suit the worker (ergonomics), and appropriate psychosocial action" [p 35].

In summary research indicates that, in general, the productive potential of the majority of older workers remains high and that age-related changes in health have a minimal effect. The attitudes and behavior of the older worker are generally considered to be highly congruent with effective organizational functioning (65). Indeed, according to Peterson \& Coberly (16), "it ... seems fair to conclude that age is not an automatic detriment to productivity" [p 124] and, further, that there is reason to believe that the work capacity of older workers may well be on the increase. In addition, as the ILO report (10) notes, "in work situations where ageing workers do encounter difficulties in coping with the demands of their job, there are several ways in which working conditions can be adjusted to maintain work capacity, preserve health, and prevent accidents" [p 47].

In terms of the current state of research, the emerging conceptual models of work capacity are the key to addressing the major issues of an aging work force. As Knowles (129) has argued, "the question 'Can older workers remain competitive?' is not the real issue facing [society] today. Rather, it is: 'How do you convince corporate [capital] that older workers are and can remain competitive?" [p 16]. A related question we would ask is "What changes are required in the workplace, in the nature and organization of work itself, in order that we, as a society, can best enhance the work capacity and, thereby, maximize the productivity of older workers?"

\section{Conclusions with respect to implications for research and policy}

Many of the documents and papers reviewed for this paper, often themselves reviews, make their own recommendations, both for further research and for corporate or social policy, to address the issues of an aging work force $(8,10-12,15$, 130). Rather than reproduce all of them, we would like to indicate briefly those that are the most relevant to the focus of this paper, namely, the effects of age-related health changes on productivity - framed as the work capacity - of older workers.

\section{Implications for future research}

It is clear from the literature reviewed for this paper that, although considerable research has been done on the health of people over 65 years of age, very little is known about the overall health (physical, psychological, social) of, and health 
changes in, middle-aged people (aged $40-65$ years). In addition, not enough is known about the extent to which certain determinants of health (eg, race or ethnicity, gender, class) produce differential rates of aging. Specifically, WHO (15) recommends that research is needed to "develop better tools for surveillance and assessment of age-specific health and employment issues" [p 35]. In addition, fundamental questions remain about the meaning of health in the workplace, for example, what precisely is workplace health; is poor health caused by work, poor health made worse or exacerbated by work, or poor health manifested through work; what about the implications of previous injury or illness for workplace health; how does workplace health relate to overall health?

Much still remains unknown in terms of the productive potential of older workers. For example, the National Advisory Council on Aging (11) asks: "What effect, if any, does aging have on continuing competency and workplace performance?' [p 23]. Sterns \& McDaniel (25) recommend that research be conducted on the physical and psychological compensatory mechanisms used by older workers. Addressing these kinds of issues, WHO (15) proposes an inclusive and extensive research agenda, including "research [that covers] not only theoretical aspects, but also the validation and evaluation of methods of adapting jobs to suit older workers" [p 35].

More research is also required on the effects of the nature of work and work conditions on the aging process; for example, are there differential rates of aging for different occupational groups? Research questions such as this highlight the conceptual difficulty of separating "natural aging" from the accumulation of life-long assaults on health, one of which may be workplace or occupational physical and psychological hazards. In this regard, ILO (10) recommends that "studies be undertaken to identify the types of activity likely to hasten the ageing process or in which older workers encounter difficulties in adapting to the demands of their work, to determine the reasons, and to devise appropriate solutions" [p 46].

ILO (10), Ilmarinen (116), Sterns \& McDaniel (25), and WHO (15) all recommend that more research on the conceptual development and application of the notion of work capacity be conducted. More precise information on job demands and the fit between job demands and job performance is required for this research task, and it would include addressing the following questions raised by the National Advisory Council on Aging (11): (i) what are the best ways to modify the workplace to fit the perceptual and cognitive needs of workers as they age and (ii) what are the most effective ways of retraining workers to prepare them for the job changes they will face as industry adopts new technologies? We also need to know more about how older workers adapt to changes in work or the workplace and how the changes might be implemented in ways which make them acceptable to older workers.

\section{Implications for corporate policy}

The research reviewed for this paper has implications for corporate policy primarily in terms of increasing the work capacity of older workers by, first, adapting work tasks, work conditions, and work arrangements and, second, providing training and reskilling opportunities so that there is more of a match between work demands and the changing capabilities of older workers. A recent report of ILO (10) reiterates its older (1980) worker recommendations to address these issues. At a general level these include modifying the forms of work organization and work time that lead to stress or to an excessive pace of work in relation to the possibilities of the workers concerned, in particular by limiting overtime; and adapting the job and its content to the worker by recourse to all available technical means and, in particular, to ergonomic principles, so as to preserve health, prevent accidents, and maintain work capacity. ILO (10) also makes more specific recommendations at the enterprise level; one such example is enabling older workers to organize their worktime and leisure to suit their convenience, particularly by facilitating part-time employment and providing for flexible workhours.

For a more-detailed discussion of further implications for corporate policy on changes in work conditions to accommodate older workers, see the IAW review paper, "Work Organization and the Aging Workforce" (128).

\section{Implications for social policy}

The conclusion of many of the documents and papers reviewed is that employment decisions about older workers recruitment, promotion, training, and retirement - should be function-based rather than age-based $(10,15,25,131)$. Associated with this conclusion are calls for legislation prohibiting age discrimination, such as the 1967 Age Discrimination in Employment Act in the United States (24). van der Velden (132) of The Netherlands goes further and recommends a comprehensive "age-conscious social policy" with respect to aging and work. He defines this as "a policy that intends to deal with the varying situations and needs of persons of different ages" [p 358]. Such a policy "not only aims at the older worker, but starts at the beginning of one's working life", and would include the following dimensions: "proactive" policy for those aged 25 years and over, such as career planning, "preventive" policy for those 45 years of age and over, such as incentives for adjusting work conditions so that workers function optimally, and "corrective" policy for those 55 years of age and over, such as flexible retirement options without jeopardizing pension status (132, pp 360-362). Clearly, social policy which addresses issues of an aging work force must include retirement policies and benefits, public pension programs and policies, as well as overall national social security systems.

This paper presented a summary of a review of relevant past and present research investigating the productivity of 
older workers. It is clear that many important research and policy issues remain unresolved and that, as concerns about the aging of the population in general and the aging of the work force in particular appear to be increasing, the issues raised will become even more pressing. We need not, however, believe ourselves to be at the mercy of demographic and economic imperatives, as if these existed outside the realm of public discussion and debate. Continued research on the issues of an aging work force, such as that presented in this paper, the longer review from which it was condensed, and the larger research project for which that review was written, are major contributions to the policy outcomes of this public discussion and debate.

\section{Acknowledgments}

The authors gratefully acknowledge the helpful comments of Fred Ashbury, Joan Eakin, Victor Marshall, Sharon SwitzerMcIntyre, and anonymous reviewers of earlier versions of this paper.

Work on this paper was supported in part by a grant from the Innovations Fund of Human Resources Development Canada for the "Issues of an Aging Workforce" (IAW) Project, Victor Marshall, Principal Investigator, Director, Institute for Human Development, Life Course and Aging, University of Toronto.

\section{References}

1. Pifer A, Bronte L. Introduction: squaring the pyramid. In: Pifer A, Bronte L, editors. Our aging society. New York (NY): WW Norton, 1986.

2. Institute for Human Development Life Course and Aging. Age, health, and work: the productivity of older workers: a literature review. Toronto $(\mathrm{ON})$ : University of Toronto, Institute for Human Development, Life Course and Aging, 1996. (Working paper series: issues of an aging workforce)

3. Rix SE. Older workers. Santa Barbara (CA): ABC-CLIO Inc, 1990.

4. Rix SE, editor. Older workers: how do they measure up?: an overview of age differences in employee costs and performance. Washington (DC): American Association of Retired Persons, Public Policy Institute, 1994.

5. Snel J, Cremer R, editors. Work and aging: a European perspective. London: Taylor and Francis Ltd, 1994.

6. Bass SA, editor. Older and active: how Americans over 55 are contributing to society. New Haven (CT): Yale University Press, 1995.

7. American Association of Retired Persons. Workers over 50: old myths, new realities. Washington (DC): American Association of Retired Persons, 1986.

8. American Association of Retired Persons. Business and older workers: current perceptions and new directions for the 1990s. Washington (DC): American Association of Retired Persons, 1989.

9. Birren JE, Robinson PK, Livingston JE, editors. Age, health, and employment. Englewood Cliffs (NJ): Prentice-Hall, 1986.
10. International Labour Office (ILO). World labour report. Geneva: ILO, 1995.

11. National Advisory Council on Aging. Older workers in an aging workforce. Ottawa (ON): Ministry of Supply and Services Canada, 1991.

12. National Advisory Council on Aging. On managing an aging labor force. Ottawa (ON): Ministry of Supply and Services Canada, 1992.

13. Sterns HL, Sterns AA. Health and the employment capability of older Americans. In: Bass SA, editor. Older and active: how Americans over 55 are contributing to society. New Haven (CT): Yale University Press, 1995:10-34.

14. Taylor PE, Walker A. The ageing workforce: employers' attitudes towards older people. Work Employment Soc 1994;8(4):569—91.

15. World Health Organization (WHO), Aging and working capacity. Geneva: WHO, 1993. (Technical report, no 835)

16. Peterson DA, Coberly S. The older worker: myths and realities. In: Morris R, Bass SA, editors. Retirement reconsidered: economic and social roles for older people. New York (NY): Springer Publishing Company, 1988:116-28.

17. Marshall VW. The older worker in Canadian society: is there a future? In: Gee EM, Gutman GM, editors. Rethinking retirement. Burnaby (BC): Simon Fraser University Press, 1995:31—50.

18. Barth $M C$, McNaught $W$. The impact of future demographic shifts on the employment of older workers. Hum Resour Manage 1991;30(1):31- 44 .

19. Kohli M, Rein M, Guillemard A-M, van Gunsteren H, editors. Time for retirement: comparative studies of early exit from the labor force. Cambridge (UK): Cambridge University Press, 1991.

20. Szeman Z. Employers' policies towards older workers in Hungary. In: Proceedings of the XIII World Congress of Sociology: comparative aspects of ageing and employment; 1994; Bielefeld, Germany.

21. Schellenberg G. Older workers in the Canadian labour market. Ottawa (ON): One Voice, The Canadian Seniors' Network, 1994.

22. Casey B, Laczko F. Early retired or long-term unemployed? Work Employment Soc 1989;3(3):509-26.

23. Walker A. Early retirement: release or refuge from the labor market? Q J Soc Aff 1985; 1(3):211—29.

24. Walker $A$, Taylor $P$. Ageism versus productive aging: the challenge of age discrimination in the labor market. In: Caro FG, Chen Y-P, editors. Achieving a productive aging society. London: Auburn House, 1993.

25. Sterns HL, McDaniel MA. Job performance and the older worker. In: Rix SE, editor. Older workers: how do they measure up? an overview of age differences in employee costs and performances. Washington (DC): American Association of Retired Persons, Public Policy Institute, 1994:27-51.

26. Wanner RA, McDonald PL. Ageism in the labor market: estimating earnings discrimination against older workers. J Gerontol 1983;38(6):738 - 44 .

27. Mitchell OS. Aging, job satisfaction, and job performance. In: Bluestone I, Montgomery RJV, Owen JD, editors. The aging of the American workforce. Detroit (MI): Wayne State University Press, 1990:242-72.

28. Loveman GW, Gabarro JJ. The managerial implications of changing workforce demographics: a scoping study. Hum Resour Manage 1991;30(1):7-29.

29. George LK. Social factors and illness. In: Binstock RH, George LK, editors. Handbook of aging and the social sciences. 3rd ed. San Diego (CA): Academic Press, 1996:229—52.

30. Welford AT. Changes of performance with age: an overview. In: Charness N, editor. Aging and human performance. Chicester (UK): John Wiley and Sons, 1985:333—69. 
31. Coates GD, Kirby RH. Organismic factors and individual differences in human performance and productivity. In: Alluisi EA Fleishman EA, editors. Human performance and productivity: stress and performance effectiveness. Hillsdale (NJ): Lawrence Erlbaum Associates, 1982:91-140.

32. Fozard JL. Vision and hearing in aging. In: Birren JE, Schaie KW, editors. Handbook of the psychology of aging. 3rd ed. San Diego (CA): Academic Press, 1990:150-70.

33. Stagner R. Aging in industry. In: Birren JE, Schaie KW, editors Handbook of the psychology of aging. 2nd ed. New York (NY): Van Nostrand Reinhold, 1985:789-817.

34. Verrillo RT, Verrillo V. Sensory and perceptual performance. In: Charness $\mathrm{N}$, editor. Aging and human performance. Chichester (United Kingdom): John Wiley and Sons, 1985:1-46.

35. Forteza JA, Prieto JM. Aging and work behavior. In: Triandis HC, Dunnette MD, Hough LM, editors. Handbook of industrial and organizational psychology; vol 4. 2nd ed. Palo Alto (CA): Consulting Psychologists Press, Inc, 1994:447_483.

36. Charness $N$. The aging worker and performance. In: Joshi A, Berger E, editors. Proceedings of the 12th Annual McMaster Summer Institute on Gerontology; 1995 June 5-7. Hamilton (ON): McMaster University, Office of Gerontological Studies, 1995.

37. Charness N, Bosman EA. Human factors and design for older adults. In: Birren JE, Schaie KW, editors. Handbook of the psychology of aging. 3rd ed. San Diego (CA): Academic Press, 1990:446-63.

38. Charness N, Bosman EA. Human factors and age. In: Craik FIM Salthouse TA, editors. Handbook of cognition and aging. Hillsdale (NJ): Lawrence Erlbaum Associates, 1992:495-551.

39. Spirduso WW, MacRae PG. Motor performance and aging. In: Birren JE, Schaie KW, editors. Handbook of the psychology of aging. 3rd ed. San Diego (CA): Academic Press, 1990:183-200.

40. Stones MJ, Kozma A. Physical performance. In: Charness N, editor. Aging and human performance. Chichester (United Kingdom) John Wiley and Sons, 1985:261 -91.

41. Jensen AR. Reaction time and psychometric g. In: Eysenck HJ, editor. A model for intelligence. Berlin: Springer-Verlag, 1982:93132.

42. Welford AT. Mental workload as a function of demand, capacity, strategy, and skill. Ergonomics 1978;21:151—67.

43. Solomon D. Age, health, and productivity: effects of aging on health and cognitive function. In: Livingston J, Robinson PK, editors Age, health, and productivity. Report to the United States Administration on Aging, 1984.

44. Robinson PK. Age, health, and job performance. In: Birren JE, Robinson PK, Livingston JE, editors. Age, health, and employment. Englewood Cliffs (NJ): Prentice-Hall, 1986:63-77.

45. Coy JA, Davenport M. Age changes in the older adult worker: Implications for injury prevention. Work 1991;2(1):38 - 46.

46. Kohn RR. Aging and age-related diseases: normal processes. In: Johnson HA, editor. Relations between normal aging and disease. New York (NY): Raven Press, 1985

47. Salthouse TA. Cognitive competence and expertise in aging. In: Birren JE, Schaie KW, editors. Handbook of the psychology of aging. 3rd ed. San Diego (CA): Academic Press, 1990:310 - 9.

48. Schaie KW. Intellectual development in adulthood. In: Birren JE Schaie KW, editors. Handbook of the psychology of aging. 3rd ed. San Diego (CA): Academic Press, 1990:291-309.

49. Cunningham WR. Intellectual abilities and age. In: Schaie KW, editors. Annual review of gerontology and geriatrics; Vol 7. New York (NY): Springer Publishing Company, 1987:117-34.

50. Salthouse TA. Initiating the formalization of theories of cognitive aging. Psychol Aging 1988;3:3-16.

51. Field D, Schaie KW, Leino EV. Continuity in intellectual func-

tioning: the role of self-reported health. Psychol Aging 1988;4:385-92.

52. Perlmutter M, Nyquist L. Relationships between self-reported physical and mental health and intelligence performance across adulthood. J Gerontol Psychol Sci 1990;45:P145-55.

53. Hultsch DF, Hammer M, Small BJ. Age differences in cognitive performance in later life: relationships to self-reported health and activity lifestyle. J Gerontol Psycholog Sci 1993;48:P1 - P11.

54. Cerella J. Aging and information-processing rate. In: Birren JE Schaie KW, editors. Handbook of the psychology of aging. 3rd ed. San Diego (CA): Academic Press, 1990:201-21.

55. Kok A, Lorist MM, Cremer R, Snel J. Age-related differences in mental work capacity: effects of task complexity and stressors on performance. In: Snel J, Cremer R, editors. Work and aging: a European perspective. London: Taylor and Francis Ltd, 1994:139_ 61.

56. Galton F. Inquiries into human faculty and its development. London: MacMillan and Company, 1883.

57. Thorndike EL. Adult learning. New York (NY): MacMillan and Company, 1928.

58. Warr P. Age and employment. In: Triandis HC, Dunnette MD Hough LM, editors. Handbook of industrial and organizational psychology; vol 4. 2nd ed. Palo Alto (CA): Consulting Psychologists Press Inc, 1994:485-550.

59. McNaught W, Barth MC. Are older workers good buys? - a case study of Days Inns of America. Sloan Manage Rev 1992;33(3):53-63.

60. Craik FIM. Age differences in human memory. In: Birren JE, Schaie KW, editors. Handbook of the psychology of aging. New York (NY): Van Nostrand Reinhold, 1977:384-420.

61. Koyl LF. Aging, health, and work. In: Parnes HS, editor. Policy issues in work and retirement. Kalamazoo (MI): WE Upjohn Institute for Employment Research, 1983.

62. Craik FIM, Morris RG, Gick ML. Adult age differences in working memory. In: Vallar G, Shallice T, editors. Neuropsychological impairments of short term memory. Cambridge (United Kingdom): Cambridge University Press, 1989.

63. Craik FIM, Jennings JM. Human memory. In: Craik FIM, Salthouse TA, editors. Handbook of aging and cognition. Hillsdale (NJ): Lawrence Erlbaum Associates, 1992:51-110.

64. Hultsch DF, Dixon RA. Learning and memory in aging. In: Birren JE, Schaie KW, editors. Handbook of the psychology of aging; 3rd ed. San Diego (CA): Academic Press, 1990:258—74.

65. Doering M, Rhodes SR, Schuster M. The aging worker; research and recommendations. Beverly Hills (CA): Sage Publications Inc, 1983.

66. Earles JL, Salthouse TA. Interrelations of age, health, and speed. J Gerontol Psychol Sci 1995;50B(1):P33__P41.

67. Birren JE. The psychology of aging. Englewood Cliffs (NJ): Prentice-Hall, 1964

68. Sterns HL. Training and retraining adult and older adult workers. In: Birren JE, Robinson PK, Livingston JE, editors. Age, health, and employment. Englewood Cliffs (NJ): Prentice-Hall, 1986:93113.

69. Sterns HL, Doverspike D. Aging and the training and learning process. In: Goldstein IL and Associates, editors. Training and development in organizations. San Francisco (CA): Jossey-Bass Publishers, 1989:299-332.

70. Bourne B. Effects of aging on work satisfaction, performance, and motivation. Aging Work 1982;5(1):37-47.

71. Rodin J. Aging and health: effects of the sense of control. Science 1986;223:1271-6

72. Rodin J. Health, control, and aging. In: Baltes MM, Baltes PB, editors. The psychology of control and aging. Hillsdale (NJ): Law- 
rence Erlbaum Associates, 1986:139—65.

73. Rowe JW, Kahn RL. Human aging: usual and successful. Science 1987;237:143-9.

74. Whitbourne SK. The me I know: a study of adult identity. New York (NY): Springer-Verlag Inc, 1986

75. Kobassa SC, Maddi SR, Kahn S. Hardiness and health: a prospective study. J Pers Soc Psychol 1982;42:168-77.

76. McDaniel MA, Schmidt FL, Hunter JE. Job experience correlates of performance. J Appl Psychol 1988;73:327-30.

77. McEnrue MD. Length of experience and the performance of managers in the establishment phase of their careers. Acad Manage J 1988;31:175-85.

78. Avolio BJ, Waldman DA, McDaniel MA. Age and work performance in non-managerial jobs: the effects of experience and occupational type. Acad Manage J 1990;33(2):407-22.

79. Avolio BJ, Waldman DA. Personnel aptitude test scores as a function of age, education and job type. Exp Aging Res 1987;13:10913.

80. Czaja SJ, Sharit J. Age differences in the performance of computerbased work. Psychol Aging 1993;8(1):59-67.

81. McEvoy GM, Cascio WF. Cumulative evidence of the relationship between employee age and job performance. J Appl Psychol 1989;74(1):11-7.

82. Sterns HL, Alexander RA. Industrial gerontology: the aging individual and work. In: Schaie KW, editor. Anmual review of gerontology and geriatrics; vol 7. New York (NY): Springer Publishing Company, 1987:243- 64

83. Davies DR, Sparrow PR. Age and work behavior. In: Charness N, editor. Aging and human performance. Chichester (United Kingdom): John Wiley and Sons, 1985:293-332.

84. Warr P. Age and job performance. In: Snel J, Cremer R, editors. Work and aging: a European perspective. London: Taylor and Francis Ltd, 1994:309-25.

85. Avolio BJ. A levels-of-analysis perspective of aging and work research. In: Schaie KW, Lawton MP, editors. Annual review of gerontology and geriatries; vol 11. New York (NY): Springer Publishing Company, 1991:239—60.

86. Waldman DA, Avolio BJ. A meta-analysis of age differences in job performance. J Appl Psychol 1986;71(1):33—8.

87. Rhodes SR. Age-related differences in work attitudes and behavior: a review and conceptual analysis. Psychol Bull 1983;93:32867.

88. Hoppock R. Comparisons of satisfied and dissatisfied teachers. Psychol Bull 1935;12:661.

89. Wright JD, Hamilton RF. Work satisfaction and age: some evidence for the job change hypothesis. Soc Forces 1978;56(2):114058.

90. Janson P, Martin JK. Job satisfaction and age: a test of two views. Soc Forces 1982;60(4):1089-102.

91. Kacmar KM, Ferris GR. Theoretical and methodological considerations in the age-job satisfaction relationship. J Appl Psychol 1989;74(2):201-7.

92. Mathieu JE, Zajac DM. A review and meta-analysis of the antecedents, correlates, and consequences of organizational commitment. Psychol Bull 1990;108(2):171-94

93. Sterns HL, Barrett GV, Alexander RA. Accidents and the aging individual. In: Birren JE, Schaie KW, editors. Handbook of the psychology of aging, 2nd ed. New York (NY): Van Nostrand Reinhold, 1985:703-24.

94. Dillingham AE. Age and workplace injuries. Aging Work 1981:4(1):1-10.

95. Root N. Injuries at work are fewer among older employees. Mon Labor Rev 1981;104(3):30 - 4.

96. Garg A. Ergonomics and the older worker: an overview. Exp Ag- ing Res 1991;17(3):143-55.

97. Taylor DE. Absences from work among full-time employees. Mon Labor Rev 1981;104(3);68-70.

98. Martocchio JJ. Age-related differences in employee absenteeism: a meta-analysis. Psychol Aging 1989;4(4):409-14.

99. Bellaby P. What is genuine sickness? the relationship between work-discipline and the sick role in a pottery factory. Sociol Health Ilness 1990;12(1):47-68.

100. Porter LW, Steers RM. Organizational, work, and personal factors in employee turnover and absenteeism. Psychol Bull 1973;80:151-76.

101. Mobley WH, Griffeth RW, Hand HH, Meglino BM. Review and conceptual analysis of the employee turnover process. Psychol Bull 1979;86(3):493-522.

102. Cotton JL, Tuttle JM. Employee turnover: a meta-analysis and review with implications for research. Acad Manage Rev 1986;11(1):55-70.

103. Anderson K, Burkhauser R. The retirement-health nexus: a new measure of an old puzzle. J Hum Resour 1985;20:315 - 30.

104. Bazzoli $G$. The early retirement decision: new empirical evidence on the influence of health. J Hum Resour 1985;20:214 34.

105. McDonald PL, Wanner RA. Retirement in Canada. Markham (ON): Butterworths, 1990.

106. Stewman S. Labor markets, aging, and health. In: Birren JE, Robinson PK, Livingston JE, editors. Age, health, and employment. Englewood Cliffs (NJ): Prentice-Hall, 1986:114—57.

107. Altman R. Incomes of the early retired. J Soc Policy 1982;11:355364.

108. Marshall VW, Daciuk J, Ballantyne P, McMullin JA. Health status after retirement: a life course perspective. In: Canadian Association on Gerontology. Proceedings of the 22nd Annual Scientific and Educational Meeting of the Canadian Association on Gerontology; 1993; Montreal (PQ). Montreal: Canadian Association on Gerontology, 1993.

109. Statistics Canada. Survey of persons not in the labor force. Ottawa $(\mathrm{ON})$ : Ministry of Supply and Services Canada, 1993.

110. McDonald PL. Retirement revisited: a secondary data analysis. Toronto (ON): University of Toronto, Institute for Human Development, Life Course and Aging, 1994. (Working paper series: issues of an sging workforce)

111. Jackson PR, Taylor PE. Factors associated with employment status in later working life. Work Employment Soc 1994;8(4):553 - 67.

112. Berkowitz M. Functioning ability and job performance as workers age. In: Borus ME, Parnes HS, Sandell SH, Seidman B, editors. The older worker. Madison (WI): Industrial Relations Research Association, 1988:87-114.

113. Metcalf $\mathrm{H}$, Thompson M. Older workers: employers' attitudes and practices. London: IMS Manpower Commentary Program, 1990. (IMS report, no 194)

114. Newquist $\mathrm{DD}$. Toward assessing health and functional capacity for policy development on workife extension. In: Birren JE, Robinson PK, Livingston JE, editors. Age, health, and employment. Englewood Cliffs (NJ): Prentice Hall, 1986:27-44.

115. Ilmarinen J. Aging, work and health. In: Snel J, Cremer R, editors. Work and aging: a European perspective. London: Taylor and Francis Ltd, 1994:47-63.

116. Marshall VW. The next half-century of aging research - And thoughts for the past. J Gerontol Soc Sci 1995;50B:S131—3.

117. Ilmarinen J, Louhevaara V. Preserving the capacity to work. Ageing Int 1994;11(2):34-6.

118. Ilmarinen J, Tuomi K, Eskelinen L, Nygard C-H, Huuhtanen P, Klockars M. Background and objectives of the Finnish research project on aging workers in municipal occupations. Scand J Work Environ Health 1991;17 suppl 1:7-11. 
119. Ilmarinen J. Aging and work: problems and solutions for promoting the work ability. In: From experience to innovation: proceedings of the 13th Triennial Congress of the International Ergonomics Association; vol 5. International Ergonomics Association, 1997:3-16.

120. van Dijk FJH, Dormolen M, Kompier MAJ, Meijman TE. Herwaarderingsmodel belasting belastbaarheid. T Soc Gezondheidszorg 1990;68:3-10.

121. Kemper HCG. Physical work and the physiological consequences for the aging worker. In: Snel J, Cremer R, editors. Work and aging: a European perspective. London: Taylor and Francis Ltd, 1994:31- 46.

122. Kahn RL. Work and health. New York (NY): John Wiley and Sons, 1981.

123. Johnson DF, Johnson JT. Managing the older worker. J Appl Gerontol 1982;1:58-66

124. Robinson PK, Livingston JE, Birren JE, editors. Aging and technological advances. New York (NY): Plenum, 1984.

125. Jacobson D. Willingness to retire in relation to job strain and type of work. Ind Gerontol 1970;13:65-74

126. Mitchell OS, Levine PB, Pozzebon S. Retirement differences by industry and occupation. Gerontologist 1988;28(4):545-51.
127. Karasek R, Theorell T. Healthy work: stress, productivity, and the reconstruction of working life. New York (NY): Basic Books Inc, 1990 .

128. Institute for Human Development, Life Course and Aging. Work organization and the aging workforce: a literature review. Toronto (ON): University of Toronto, Institute for Human Development, Life Course and Aging, 1994. Working paper series: issues of an aging workforce.

129. Knowles DE. Dispelling myths about older workers. In: Axel H, editor. Employing older Americans: opportunities and constraints. NewYork(NY): Conference Board, 1988.

130. Copperman LF, Keast FD. Adjusting to an older workforce. New York (NY): Van Nostrand Reinhold, 1983.

131. Burtless G. Introduction and summary. In: Burtless G, editor. Work, health, and income among the elderly. Washington (DC): The Brookings Institution, 1987:1-18.

132. van der Velden J. Age-conscious social policy. In: Snel J, Creme R, editors. Work and aging: a European perspective. London: Taylor and Francis Ltd, 1994:353-64

Received for publication: 23 May 1997 